\title{
Design, Synthesis and biological evaluation of some novel indole derivatives as selective COX-2 inhibitors
}

\author{
Khaled R. A. Abdellatif ${ }^{1,2}$, Mohammed T. Elsaady ${ }^{3}$, Noha.H.Amin ${ }^{3}$, Ahmed A. Hefny ${ }^{3 *}$ \\ ${ }^{1}$ Department of Pharmaceutical Organic chemistry, Faculty of Pharmacy, Beni-suef University, Beni-suef 62514, Egypt. \\ ${ }^{2}$ Pharmaceutical Sciences Department, IbnSina National College for Medical Studies, Jeddah 21418, Kingdom of Saudi Arabia. \\ ${ }^{3}$ Department of Medicinal Chemistry, Beni-Suef University, Beni-Suef 62514, Egypt.
}

\begin{tabular}{l} 
ARTICLE INFO \\
\hline Article history: \\
Received on: $28 / 06 / 2017$ \\
Accepted on: 05/08/2017 \\
Available online: 30/08/2017 \\
\hline Key words: \\
NSAIDS; Cyclooxygenase; \\
Indomethacin; Anti- \\
inflammatory activity; \\
Ulcerogenicity. \\
\hline
\end{tabular}

\section{INTRODUCTION}

Non-steroidal anti-inflammatory drugs (NSAIDs) are among the most widely used therapeutics. Through their antiinflammatory, anti-pyretic and analgesic activities, they represent a choice treatment in various inflammatory diseases, especially arthritis, as well as relieving the pains of everyday life (AbuoRahma et al., 2014, Abdellatif et al., 2015). Their activity usually arises from inhibition of cyclooxygenase (COX) enzyme which mediates the bioconversion of arachidonic acid to inflammatory prostaglandins (PGs) and thromboxanes (TXs) (Zebardast et al., 2009, Abdelazeem et al., 2014). Cyclooxygenase enzyme exists in two distinct isoforms, a constitutive form (COX-1) and an inducible one (COX-2). The constitutive COX-1 isozyme is produced normally in a variety of tissues and is important to perform physiological functions such as gastro protection and

* Corresponding Author

Tel.:(002)-01000541747; e-mail: dr.ahmedhefney12 @yahoo.com vascular homeostasis. In contrast, $\mathrm{COX}-2$ is induced during pathological processes such as inflammation and various cancer types (Rathish et al., 2009, Al-Hourani et al., 2011, Hassan et al., 2014). Despite of their activity, many of NSAIDs, such as aspirin (1), ibuprofen (2) and indomethacin (3), have pronounced side effects such as gastrointestinal and renal toxicity resulting from the inhibition of gastro protective PGs synthesized through COX1pathway (Abdellatif et al., 2009, Abdelazeem et al., 2015). Thus, it was though those more selective COX-2 inhibitors would have reduced side effects. Based upon a number of selective $\mathrm{COX}-2$ inhibitors such as celecoxib (4), rofecoxib (5) and valdecoxib (6) were developed as safer NSAIDs with improved gastric safety profile. However, the recent market removal of some COXIBs such as rofecoxib and valdecoxib due to their adverse cardiovascular side effects clearly encourages the researchers to explore and evaluate alternative templates with COX-2 inhibitory activity (Dogné et al., 2005, Chowdhury et al., 2010, Huang et al., 2010). 
A large number of studies (Hu et al., 2003, Kalgutkar et al., 2005, Khanna et al., 2006) have used the indole ring based NSAIDs as in Indomethacin (3), as a target to improve their COX2 selectivity and reduce their ulcerogenic side effects attributed to their high COX-1 selectivity and the acidic properties of the drug. Also, in recent studies, novel series of indomethacin analogs $7 \mathbf{a}-\mathbf{f}$ (Abdellatif et al., 2016) and 8a-h (Lamie et al., 2016) were synthesized which were approved as good COX-2 selective inhibitors. So, these results encouraged us to continue the research on such type of compounds. Our strategy in this research is based on maintaining the potency of the indomethacin by keeping the main scaffold of the drug with trials to increase COX-2 selectivity via the modifications of the side groups. We now describe the synthesis, in vitro evaluation as COX-1/COX-2 inhibitors, in vivo anti-inflammatory(AI) activity, and ulcerogenic liability for a new series of $\mathrm{N}$-substituted indole derivatives as indomethacin analogs 13a-f in which, (i) the $-\mathrm{CH}_{2} \mathrm{COOH}$ moiety in position 3 of indomethacin was replaced with an aromatic moiety containing phenyl hydrazine substituted with $\mathrm{COX}-2$ pharmacophore, $\mathrm{SO}_{2} \mathrm{Me}$ in 11a,d or $\mathrm{SO}_{2} \mathrm{NH}_{2}$ in 11b,e or with methyl group in 11c,f to evaluate the effect of these groups on COX selectivity and antiinflammatory activity, (ii) the chlorobenzoyl moiety of indomethacin in position 1, which is important for antiinflammatory activity, is maintained in 11d, 11e, 11f or replaced with benzoyl in 10a, 10b, 10c, and (iii) methyl group at position 2 and methoxy group at position 5 was removed in all compounds.

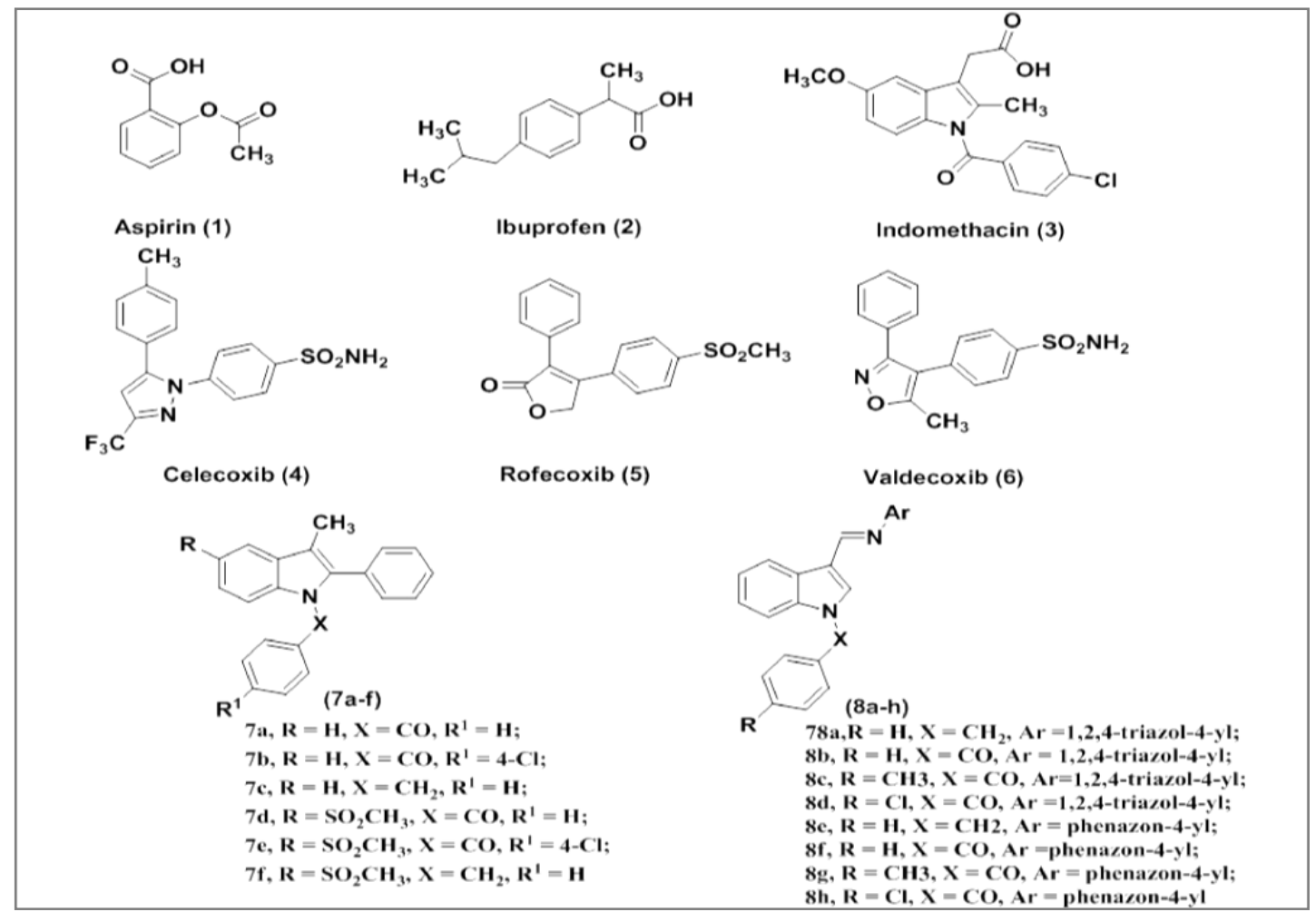

Fig. 1: Chemical structures of some traditional NSAIDs (1-3), some selective COX-2 inhibitor drugs (4-6) and reported indomethacin analogs (7a-f and 8a-h).

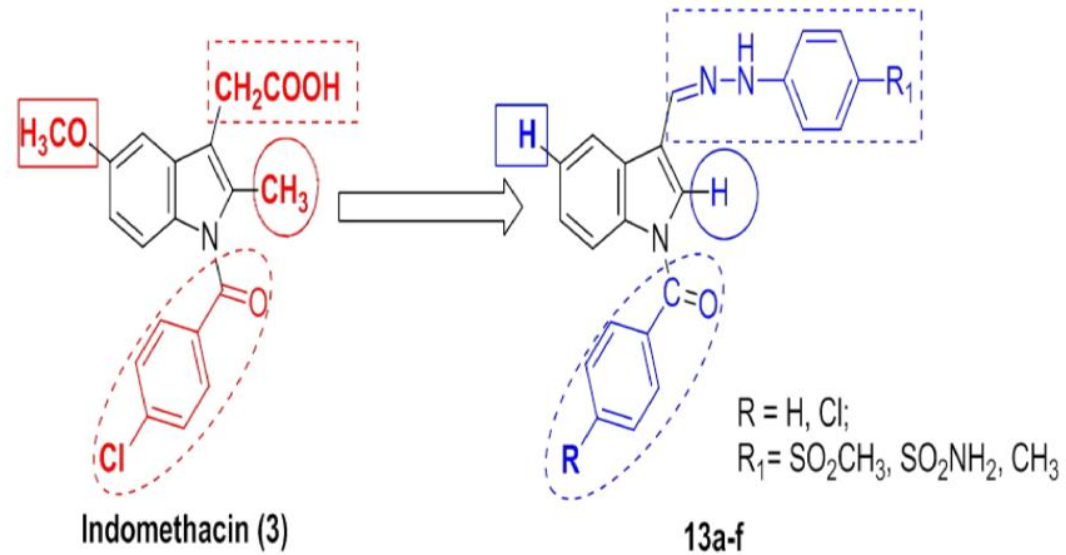

Fig. 2: Chemical structures of indomethacin (3) and the designed $\mathrm{N}$-substituted indole derivatives 13a-f. 


\section{MATERIALS AND METHODS}

\section{Instrument and reagents}

Melting points were determined on a Thomas-Hoover capillary apparatus and are uncorrected. Infrared (IR) spectra were recorded as films on $\mathrm{KBr}$ plates using a Nicolet 550 Series II Magna FT-IR spectrometer. ${ }^{1} \mathrm{H}$ NMR and ${ }^{13} \mathrm{C}$ NMR spectra were measured on a Bruker Avance III $400 \mathrm{MHz}$ spectrophotometer, Faculty of Pharmacy, Beni-Suef University, Egypt in DMSO- $d_{6}$ with TMS as the internal standard, where $J$ (coupling constant) values are estimated in Hertz $(\mathrm{Hz})$ and chemical shifts were recorded in ppm on $\delta$ scale. Mass spectra (MS) were recorded on Hewlett Packard 5988 spectrometer. Microanalyses for C, H and N were carried out on Perkin-Elmer 2400 analyzer (Perkin-Elmer, Norwalk, CT, USA) at the regional center for mycology and Biotechnology, Al-Azhar University, Egypt. Silica gel column chromatography was performed using Merck silica gel 60 ASTM (70-120 mesh). All other reagents, indole (9) and p-tolylhydrazine hydrochloride (12c) were purchased from the Aldrich Chemical Company (Milwaukee, WI), were used without further purification.

\section{Chemistry}

Indole-3-carboxaldehyde (10)(Guillon et al., 2011, Kumar et al., 2012); 1-benzoyl-1H-indole-3-carbaldhyde (11a) (Wang et al., 2012); 1-(4-chlorobenzoyl)-1H-indole-3-carbaldhyde (11b)(Singh et al., 2010); (4-methylsulphonylphenyl) hydrazine hydrochloride (12a)(Abdellatif et al., 2008) and (4aminosulphonylphenyl) hydrazine hydrochloride (12b)(Abdellatif et al., 2008) were prepared according to the reported procedures.

\section{General procedure for the synthesis of (4-substitutedphenyl)(3- ((2-(4- substitutedphenyl)hydrazono)methyl)-1H-indol-1- $y l) m e t h a n o n e ~ 13 a-f$}

A mixture of $11 \mathrm{a}$ or $11 \mathbf{b}(0.3 \mathrm{gm}, 1 \mathrm{mmol})$ and the appropriate phenyl hydrazine hydrochloride derivative 12a-c (1.2 $\mathrm{mmol})$ in absolute ethanol $(10 \mathrm{~mL})$ and glacial acetic acid $(1 \mathrm{ml})$ was refluxed for $5-7 \mathrm{~h}$ (monitored by TLC). The precipitate that formed on hot was filtered off, dried and recrystallized from $95 \%$ ethanol to afford 13a-f

(3-((2-(4-(methylsulfonyl)phenyl)hydrazono)methyl)-1H-indol-1$y l)($ phenyl)- methanone (13a)

Yellow solid; Yield 72\%; mp 191-193 ${ }^{\circ} \mathrm{C}$; IR (KBr) 3298 (NH), 3059, 3024 (CH aromatic), 2924, 2854 (CH aliphatic), 1685 $(\mathrm{C}=\mathrm{O}), 1597(\mathrm{C}=\mathrm{N}), 1323,1138\left(\mathrm{SO}_{2}\right) \mathrm{cm}^{-1} ;{ }^{1} \mathrm{H}$ NMR (DMSO-d $)$ $\delta 3.12\left(\mathrm{~s}, 3 \mathrm{H}, \mathrm{SO}_{2} \mathrm{CH}_{3}\right), 7.22(\mathrm{~d}, 2 \mathrm{H}, J=8.8 \mathrm{~Hz}$, phenyl H-3, H-5), $7.48(\mathrm{~d}, 2 \mathrm{H}, J=9.2 \mathrm{~Hz}$, phenyl H-2, H-6), $7.64(\mathrm{~d}, 2 \mathrm{H}, J=8 \mathrm{~Hz}$, indole $\mathrm{H}-5, \mathrm{H}-6), 7.71$ (s, $1 \mathrm{H}$, indole $\mathrm{H}-2), 7.76(\mathrm{~d}, 2 \mathrm{H}, J=8.8 \mathrm{~Hz}$, benzoyl H-3, H-5), 7.81-7.86 (m, 3H, benzoyl H-2, H-4, H-6), $8.17(\mathrm{~s}, 1 \mathrm{H}, \mathrm{CH}=\mathrm{N}), 8.33$ (d, $1 \mathrm{H}, J=8.8 \mathrm{~Hz}$, indole $\mathrm{H}-7), 8.46$ (d, $1 \mathrm{H}, J=8.8 \mathrm{~Hz}$, indole $\mathrm{H}-4), 10.93\left(\mathrm{~s}, 1 \mathrm{H}, \mathrm{NH}, \mathrm{D}_{2} \mathrm{O}\right.$ exchangeable); ${ }^{13} \mathrm{C}$ NMR (DMSO- $\left.d_{6}\right) \delta 44.78\left(\mathrm{SO}_{2} \mathrm{CH}_{3}\right), 111.78,116.35,118.28$, 122.94, 125.19, 126.16, 127.70, 129.31, 129.49, 129.61, 129.66,
$130.06, \quad 132.75, \quad 134.24, \quad 136.25, \quad 136.86, \quad 149.62(\mathrm{CH}=\mathrm{N})$, 168.58 $(C=\mathrm{O})$; $\mathrm{MS} \mathrm{m} / \mathrm{z}(\mathrm{ES}+) 417.48\left(\mathrm{M}^{+}\right)$. Anal. Calcd for $\mathrm{C}_{23} \mathrm{H}_{19} \mathrm{~N}_{3} \mathrm{O}_{3} \mathrm{~S}$ : C, 66.17; H, 4.59; N, 10.07. Found: C, 65.89; H, $4.71 ; \mathrm{N}, 10.34$.

\section{4-(2-((1-benzoyl-1H-indol-3-yl) methylene) hydrazinyl) benzenesulfonamide (13b)}

Brown solid; Yield 65\%; mp 211-213 ${ }^{\circ} \mathrm{C}$; IR (KBr) 3429, 3321 (NH2), $3290(\mathrm{NH}), 3116,3062$ (CH aromatic), 2924, 2854 ( $\mathrm{CH}$ aliphatic), $1662(\mathrm{C}=\mathrm{O}), 1597(\mathrm{C}=\mathrm{N}), 1327,1153\left(\mathrm{SO}_{2}\right)$ $\mathrm{cm}^{-1} ; \quad{ }^{1} \mathrm{H} \quad \mathrm{NMR} \quad\left(\mathrm{DMSO}-d_{6}\right) \quad \delta \quad 7.08 \quad\left(\mathrm{~s}, \quad 2 \mathrm{H}, \quad \mathrm{NH}_{2}, \quad \mathrm{D}_{2} \mathrm{O}\right.$ exchangeable), $7.16(\mathrm{~d}, 2 \mathrm{H}, J=8.8 \mathrm{~Hz}$, phenyl H-2, H-6), 7.35 (d, $2 \mathrm{H}, J=7.6 \mathrm{~Hz}$, phenyl H-3, H-5), 7.44-7.62 (m, 5H, indole H-2, H5, H-6, benzoyl H-3, H-5), 7.71-7.77 (m, 3H, benzoyl H-2, H-4, $\mathrm{H}-6), 8.14(\mathrm{~s}, 1 \mathrm{H}, \mathrm{CH}=\mathrm{N}), 8.32(\mathrm{~d}, 1 \mathrm{H}, J=9.2 \mathrm{~Hz}$, indole $\mathrm{H}-7)$, $8.44(\mathrm{~d}, 1 \mathrm{H}, J=9.2 \mathrm{~Hz}$, indole $\mathrm{H}-4), 10.74\left(\mathrm{~s}, 1 \mathrm{H}, \mathrm{NH}, \mathrm{D}_{2} \mathrm{O}\right.$ exchangeable); ${ }^{13} \mathrm{C}$ NMR (DMSO- $\left.d_{6}\right) \delta 44.78\left(\mathrm{SO}_{2} \mathrm{CH}_{3}\right), 111.35$, $116.29,118.25,122.96,125.14,126.18,126.74,128.01,129.36$, $129.48, \quad 129.74, \quad 131.60, \quad 133.07, \quad 133.64, \quad 135.14,136.19$, 148.12(CH=N), 167.59(C=O); MS $\mathrm{m} / \mathrm{z}(\mathrm{ES}+) 418.47\left(\mathrm{M}^{+}\right)$. Anal. Calcd for $\mathrm{C}_{22} \mathrm{H}_{18} \mathrm{~N}_{4} \mathrm{O}_{3} \mathrm{~S}$ : C, 63.14; H, 4.34; N, 13.39. Found: C, 63.25; H, 4.46; N, 13.61 .

\section{phenyl(3-((2-(p-tolyl)hydrazono) methyl)- 1H-indol-1-yl) methanone $(13 c)$}

Yellow solid; Yield 80\%; mp 146-148 ${ }^{\circ} \mathrm{C}$; IR (KBr) 3298 (NH), 3028 (CH aromatic), 2954, 2912, 2854 (CH aliphatic), 1662 $(\mathrm{C}=\mathrm{O}), 1543(\mathrm{C}=\mathrm{N}) \mathrm{cm}^{-1} ;{ }^{1} \mathrm{H}$ NMR (DMSO-d $) \delta 2.23(\mathrm{~s}, 3 \mathrm{H}$, CH3), 7.00 (d, 2H, $J=7.6 \mathrm{~Hz}$, phenyl H-2, H-6), 7.08 (d, 2H, $J=$ $8 \mathrm{~Hz}$, phenyl H-3, H-5), 7.47 (d, 2H, $J=7.6 \mathrm{~Hz}$, indole $\mathrm{H}-5, \mathrm{H}-6)$, $7.63(\mathrm{~d}, 2 \mathrm{H}, J=7.6 \mathrm{~Hz}$, benzoyl H-3, H-5), 7.71-7.77 (m, $2 \mathrm{H}$, benzoyl $\mathrm{H}-4$, indole $\mathrm{H}-2), 7.80(\mathrm{~d}, 2 \mathrm{H}, J=7.6 \mathrm{~Hz}$, benzoyl $\mathrm{H}-2, \mathrm{H}-$ 6), $8.02(\mathrm{~s}, 1 \mathrm{H}, \mathrm{CH}=\mathrm{N}), 8.32(\mathrm{~d}, 1 \mathrm{H}, J=6.8 \mathrm{~Hz}$, indole $\mathrm{H}-7), 8.45$ $(\mathrm{d}, 1 \mathrm{H}, J=6.8 \mathrm{~Hz}$, indole $\mathrm{H}-4), 10.19\left(\mathrm{~s}, 1 \mathrm{H}, \mathrm{NH}, \mathrm{D}_{2} \mathrm{O}\right.$ exchangeable); ${ }^{13} \mathrm{C}$ NMR (DMSO- $\left.d_{6}\right) \delta 20.75\left(\mathrm{CH}_{3}\right), 112.24$, $116.34,119.06,122.98,125.00,125.99,127.46,128.04,128.14$, $129.26, \quad 129.59, \quad 130.10, \quad 132.03,132.60,134.34,136.84$, 143.65 $(\mathrm{CH}=\mathrm{N}), 168.49(C=\mathrm{O})$; MS $\mathrm{m} / \mathrm{z}(\mathrm{ES}+) 353.42\left(\mathrm{M}^{+}\right)$. Anal. Calcd for $\mathrm{C}_{23} \mathrm{H}_{19} \mathrm{~N}_{3} \mathrm{O}$ : C, 78.16; H, 5.42; N, 11.89. Found: $\mathrm{C}$, 77.89; H, 5.86; N, 12.04 .

\section{(4-chlorophenyl)(3-((2-(4-(methylsulfonyl) phenyl) hydrazono) methyl)-1H-indol-1-yl)methanone (13d)}

Buff powder; Yield 81\%; mp 202-204 ${ }^{\circ} \mathrm{C}$; IR (KBr) 3302 (NH), 3093, 3051 (CH aromatic), 2924, 2839 (CH aliphatic), 1678 $(\mathrm{C}=\mathrm{O}), 1593(\mathrm{C}=\mathrm{N}), 1327,1091\left(\mathrm{SO}_{2}\right) \mathrm{cm}^{-1} ;{ }^{1} \mathrm{H}$ NMR (DMSO-d $)$ $\delta 3.12\left(\mathrm{~s}, 3 \mathrm{H}, \mathrm{SO}_{2} \mathrm{CH}_{3}\right), 7.22(\mathrm{~d}, 2 \mathrm{H}, J=8.8 \mathrm{~Hz}$, phenyl H-3, H-5), 7.49 (d, 2H, $J=9.2 \mathrm{~Hz}$, phenyl H-2, H-6), 7.70 (d, $2 \mathrm{H}, J=8.4 \mathrm{~Hz}$, indole $\mathrm{H}-5, \mathrm{H}-6), 7.76$ (d, 2H, $J=8.8 \mathrm{~Hz}$, benzoyl H-3, H-5), 7.847.89 ( $\mathrm{m}, 3 \mathrm{H}$, benzoyl H-2, H-6, indole $\mathrm{H}-2), 8.16$ (s, $1 \mathrm{H}, \mathrm{CH}=\mathrm{N})$, $8.31(\mathrm{~d}, 1 \mathrm{H}, J=8.8 \mathrm{~Hz}$, indole $\mathrm{H}-7), 8.42$ (d, $1 \mathrm{H}, J=8.8 \mathrm{~Hz}$, indole $\mathrm{H}-4), 10.95$ (s, 1H, NH, D $2 \mathrm{O}$ exchangeable); ${ }^{13} \mathrm{C}$ NMR (DMSO- $d_{6}$ ) $\delta 44.82\left(\mathrm{SO}_{2} \mathrm{CH}_{3}\right), 111.80,116.62,118.40,123.05,125.27$, $126.54,127.91,129.45,129.58,129.87,130.00,130.14,132.95$, 
$134.52,136.28,137.00,149.65(\mathrm{CH}=\mathrm{N}), 168.78(C=\mathrm{O}) ; \mathrm{MS} \mathrm{m} / \mathrm{z}$ (ES+) $451.93\left(\mathrm{M}^{+}\right)$. Anal. Calcd for $\mathrm{C}_{23} \mathrm{H}_{18} \mathrm{ClN}_{3} \mathrm{O}_{3} \mathrm{~S}: \mathrm{C}, 61.13 ; \mathrm{H}$, $4.01 ; \mathrm{N}, 9.30$. Found: C, 61.42; H, 4.18; N, 9.56 .

\section{4-(2-((1-(4-chlorobenzoyl)-1H-indol-3-yl)methylene) hydrazinyl) benzene-sulfonamide (13e)}

Reddish brown solid; Yield 78\%; mp 140-142 ${ }^{\circ} \mathrm{C}$; IR (KBr) 3436, 3332 (NH2), $3294(\mathrm{NH}), 3089,3051$ (CH aromatic), 2924, 2850 (CH aliphatic), $1678(\mathrm{C}=\mathrm{O}), 1593(\mathrm{C}=\mathrm{N}), 1329,1153$ $\left(\mathrm{SO}_{2}\right) \mathrm{cm}^{-1} ;{ }^{1} \mathrm{H}$ NMR (DMSO- $\left.d_{6}\right) \delta 7.08\left(\mathrm{~s}, 2 \mathrm{H}, \mathrm{NH}_{2}, \mathrm{D}_{2} \mathrm{O}\right.$ exchangeable), 7.16 (d, 2H, $J=8.8 \mathrm{~Hz}$, phenyl H-2, H-6), 7.49 (d, $2 \mathrm{H}, J=8.8 \mathrm{~Hz}$, phenyl H-3, H-5), 7.69-7.72 (m, 3H, indole $\mathrm{H}-2, \mathrm{H}-$ 5, H-6), 7.84-7.87 (m, 4H, benzoyl H-2, H-3, H-5, H-6), 8.13 (s, $1 \mathrm{H}, \mathrm{CH}=\mathrm{N}), 8.33$ (d, $1 \mathrm{H}, J=9.2 \mathrm{~Hz}$, indole $\mathrm{H}-7), 8.43$ (d, $1 \mathrm{H}, J=$ 9.2Hz, indole $\mathrm{H}-4), 10.77\left(\mathrm{~s}, 1 \mathrm{H}, \mathrm{NH}, \mathrm{D}_{2} \mathrm{O}\right.$ exchangeable); ${ }^{13} \mathrm{C}$ NMR $\left(\mathrm{DMSO}-d_{6}\right) \delta 111.47,116.37,118.42,123.02,125.38$, $126.24,126.85,128.05,129.40,129.52,129.88,131.60,133.12$, $133.71,135.23,136.22,148.27(\mathrm{CH}=\mathrm{N}), 167.82(C=\mathrm{O}) ; \mathrm{MS} \mathrm{m} / \mathrm{z}$ (ES+) $452.91\left(\mathrm{M}^{+}\right)$. Anal. Calcd for $\mathrm{C}_{22} \mathrm{H}_{17} \mathrm{ClN}_{4} \mathrm{O}_{3} \mathrm{~S}$ : C, 58.34; H, 3.78; N, 12.37. Found: C, 58.62; H, 3.91; N, 12.48 .

\section{(4-chlorophenyl)(3-((2-(p-tolyl)hydrazono)methyl)-1H-indol-1- yl)methanone (13f)}

Yellow solid; Yield 76\%; mp 192-194 ${ }^{\circ} \mathrm{C}$; IR (KBr) 3286 (NH), 3032 (CH aromatic), 2939, 2912, 2854 (CH aliphatic), 1654 $(\mathrm{C}=\mathrm{O}), 1543(\mathrm{C}=\mathrm{N}) \mathrm{cm}^{-1}$; ${ }^{1} \mathrm{H}$ NMR (DMSO-d $)_{6} \delta 2.23(\mathrm{~s}, 3 \mathrm{H}$, CH3), 7.00 (d, 2H, $J=8 \mathrm{~Hz}$, phenyl H-2, H-6), 7.07 (d, 2H, $J=$ $8 \mathrm{~Hz}$, phenyl H-3, H-5), 7.46 (d, 2H, $J=7.6 \mathrm{~Hz}$, indole $\mathrm{H}-5, \mathrm{H}-6)$, 7.68-7.73 (m, 3H, benzoyl H-3, H-5, indoleH-2), 7.83 (d, 2H, $J=$ $8.4 \mathrm{~Hz}$, benzoyl H-2, H-6), $8.00(\mathrm{~s}, 1 \mathrm{H}, \mathrm{CH}=\mathrm{N}), 8.34$ (d, $1 \mathrm{H}, J=$ $6.8 \mathrm{~Hz}$, indole $\mathrm{H}-7), 8.45$ (d, $1 \mathrm{H}, J=7.2 \mathrm{~Hz}$, indole $\mathrm{H}-4), 10.22$ (s, $1 \mathrm{H}, \mathrm{NH}, \mathrm{D}_{2} \mathrm{O}$ exchangeable); ${ }^{13} \mathrm{C}$ NMR (DMSO- $\left.d_{6}\right) \delta 20.75\left(\mathrm{CH}_{3}\right)$, 112.24, 116.37, 119.25, 123.01, 125.10, 126.06, 127.49, 128.06, $128.14,129.37,130.11,131.55,131.94,133.23,136.84,137.36$, 143.61 $(\mathrm{CH}=\mathrm{N}), 167.53(C=\mathrm{O}) ; \mathrm{MS} m / z(\mathrm{ES}+) 387.86\left(\mathrm{M}^{+}\right)$. Anal. Calcd for $\mathrm{C}_{23} \mathrm{H}_{18} \mathrm{ClN}_{3} \mathrm{O}: \mathrm{C}, 71.22 ; \mathrm{H}, 4.68 ; \mathrm{N}, 10.83$. Found: C, 70.96; H, 4.60; N, 11.09 .

\section{Biological evaluation Animals}

Adult male Wister albino rats (120-150 g) were obtained from the animal house, (Nahda University, Beni-Suef, Egypt) were used throughout the study and were kept at controlled conditions (temperature $27 \pm 2{ }^{\circ} \mathrm{C}$, humidity $60 \pm 10 \%$ ) and a 12/12 h light/dark cycle. The animals were housed in stainless steel cages, divided into groups of four animals each and deprived of food not water $24 \mathrm{~h}$ before the experiment. All procedures relating to animal care and treatments were conducted in accordance with protocols approved by the Research Ethical Committee of Faculty of Pharmacy Beni-Suef University (2017-Beni-Suef, Egypt).

\section{COX-1/COX-2 inhibition colorimetric assay}

The ability of tested compounds listed in Table 1 was measured using colorimetric COX (ovine) Inhibitor Screening
Assay Kit (catalog no.560131, Cayman Chemical, Ann Arbor, MI, USA) according to the previous reported method(Roschek Jr et al., 2009). This assay directly measures $\mathrm{PGF}_{2 \alpha}$ that was produced by stannous chloride reduction of $\mathrm{COX}$ derived $\mathrm{PGH}_{2}$ by enzyme immunoassay.

\section{Carrageenan-induced rat paw edema assay}

The anti-inflammatory activity of newly synthesized indomethacin derivatives was evaluated by using carrageenaninduced rat paw edema test (El-Nezhawy et al., 2013). Rats were divided into 9 groups (4 animals per each group) then, they were administered with a suspension of vehicle, tested compounds or indomethacin in $10 \%$ DMSO at a dose of $10 \mathrm{mg} / \mathrm{kg}$ orally (one group per one compound). After $30 \mathrm{~min}$, the rats received $100 \mu \mathrm{L}$ of carrageenan (1\% in saline) subcutaneously on the sub plantar region of the left hind paw. The left paw thickness was measured after 1,3 and $6 \mathrm{~h}$ after carrageenan injection. The right hind paw served as a reference of non-inflamed paw for comparison. Results are expressed as percentage decrease in edema thickness induced by carrageenan. Compounds 13a, 13b, 13d, 13e and indomethacin were experimented for calculating $\mathrm{ED}_{50}$ values by using at least three doses and the paw thickness was measured after $3 \mathrm{~h}$ after carrageenan injection.

\section{Ulcerogenic liability}

The most potent Compounds 13a, 13b, 13d, 13e and indomethacin were experimented for their ulcerogenic liability according to the reported method (Abdellatif et al., 2015). Rats were divided into 6 groups of 5 animals each, and then were fasted for about $18 \mathrm{~h}$ before drug administration. The 4 tested compounds and indomethacin as a reference drug were given orally at a dose of $10 \mathrm{mg} / \mathrm{kg}$ suspended in $10 \%$ DMSO while, remaining group received DMSO as a control negative group. Treatment was continued once daily for 3 successive days in all groups. At fourth day, one hour after the last dose, animals were sacrificed under general anesthesia and stomachs were removed, collected, opened along the greater curvature, washed with distilled water and rinsed with saline. The gastric mucosa of each stomach was examined for the presence of lesions by using magnifying lens (10X). The number of mucosal lesions which appeared as red spots was counted, and their severity was determined and graded from 0-4.

The following parameters were calculated:

1- $\%$ Incidence $/ 10=[$ Number of rats showing ulcer of any grade divided by total number of rats in the group $\mathrm{x}$ 100]/10

2- Average number of ulcer $=$ Number of ulcer in the group/ total number of rats in the group

3- Average severity $=\sum$ [each ulcer multiplied by its score of severity/ number of ulcer in the group.

4- Ulcer index $=$ the sum of the above three parameters. $(\%$ Incidence $/ 10+$ Average number of ulcer + Average severity) Ulcer index value was compared to that of indomethacin. 


\section{Molecular Docking}

The 3D crystal structure of valdecoxib bound at the COX-2 (PDB:ID 2AW1) active sites (Abdellatif et al., 2008), obtained from protein data bank at research collaboration for structural Bioinformatics (RSCB) protein database [PDB]. Preparation of the synthesized compounds $13 \mathrm{~d}$ and $13 \mathrm{e}$ for docking was achieved via their 3D structure built by Molecular Operating Environment (MOE, Version 2014.09, Chemical Computing Group Inc., Montreal, Quebec, Canada). They were 3D protonated and subjected to energy minimization using MMFF94 force field with 0.05 gradient. Preparation of the enzyme for docking was achieved as follows: (1) The Co-crystallized ligand and water molecules were removed. (2) The enzyme was 3D protonated, in which hydrogen atoms were added to their standard geometry, the partial charges were computed and the system was optimized. The conformers generated were docked into the COX-2 receptor with MOE-DOCK using the triangle matcher placement method and the London $\mathrm{dG}$ scoring function. A molecular mechanics force field refinement was carried out on the top 100 poses generated. Docking for the synthesized compounds was applied. Amino acid interactions and the hydrogen bond lengths were summarized in (Table 4).

\section{RESULTS AND DISCUSSIONS}

\section{Chemistry}

The synthesis of the new compounds (4substitutedphenyl)(3-((2-(4- substitutedphenyl)hydrazono)methyl)1H-indol-1-yl)methanone derivatives was achieved through using the reaction sequence illustrated in Scheme 1. The starting material indole-3-carbaldehyde 10 was prepared in a good yield (70\%) via vilsmeier reaction, and then reacted with benzoyl or $\mathrm{p}$ - chloro benzoyl chloride in dry DMF under basic condition using $\mathrm{NaH}$ to give compounds $11 \mathrm{a}-\mathrm{b}$. Compounds $11 \mathrm{a}-\mathrm{b}$ were allowed to react with 4-methylsulfonyl- phenylhydrazine hydrochloride 12a, 4aminosulphonylphenylhydrazine hydrochloride $12 \mathrm{~b}$ or 4 methylphenylhydrazine hydrochloride $12 \mathrm{c}$ in absolute ethanol under reflux conditions to give target compounds 13a-f in good yields $(65-80 \%)$.

All the newly synthesized compounds 13a-f has been characterized by IR, 1HNMR, 13CNMR, mass spectra, and elemental analyses. The IR spectra of these compounds showed the appearance of a sharp singlet peak at 3302-3286 cm-1 corresponding to NH group, two sharp peaks at 1654-1685 and 1543-1597 cm-1 corresponding to $\mathrm{C}=\mathrm{O}$ and $\mathrm{C}=\mathrm{N}$ respectively. While, compounds such as $13 \mathrm{a}, \mathrm{b}, \mathrm{d}, \mathrm{e}$ exhibited two sharp peaks at 1323-1329 and 1138-1153 cm-1 corresponding to SO2, in addition to a forked peak at 3436-3429 and 3332-3321 cm-1 corresponding to $\mathrm{NH} 2$ for compounds $13 \mathrm{~b}$,e.

Also, 1HNMR spectra for indole derivatives showed singlet peak at $\delta 3.12$ or 7.08 or 2.23 corresponding to $\mathrm{SO} 2 \mathrm{CH} 3$ for compounds 13a,d or SO2NH2 for compounds 13b,e or $\mathrm{CH} 3$ for compounds 13c,f. Additionally, all compounds exhibited two singlet peaks at $\delta 8.00-8.17$ and $10.19-10.95$ corresponding to $\mathrm{CH}=\mathrm{N}$ and $\mathrm{NH}$ respectively. Finally, 13CNMR spectra showed peak at $\delta 44.78-44.82$ corresponding to $\mathrm{SO} 2 \mathrm{CH} 3$ for compounds 13a,d, peak at $\delta 20.75$ for $\mathrm{CH} 3$ for compounds $13 \mathrm{~b}$,e and absence of aliphatic carbons for compounds 13c,f. Two other peaks appeared at $\delta 143.61-149.65$ and $167.53-168.78$ corresponding to $\mathrm{CH}=\mathrm{N}$ and $\mathrm{C}=\mathrm{O}$ for all final compounds.

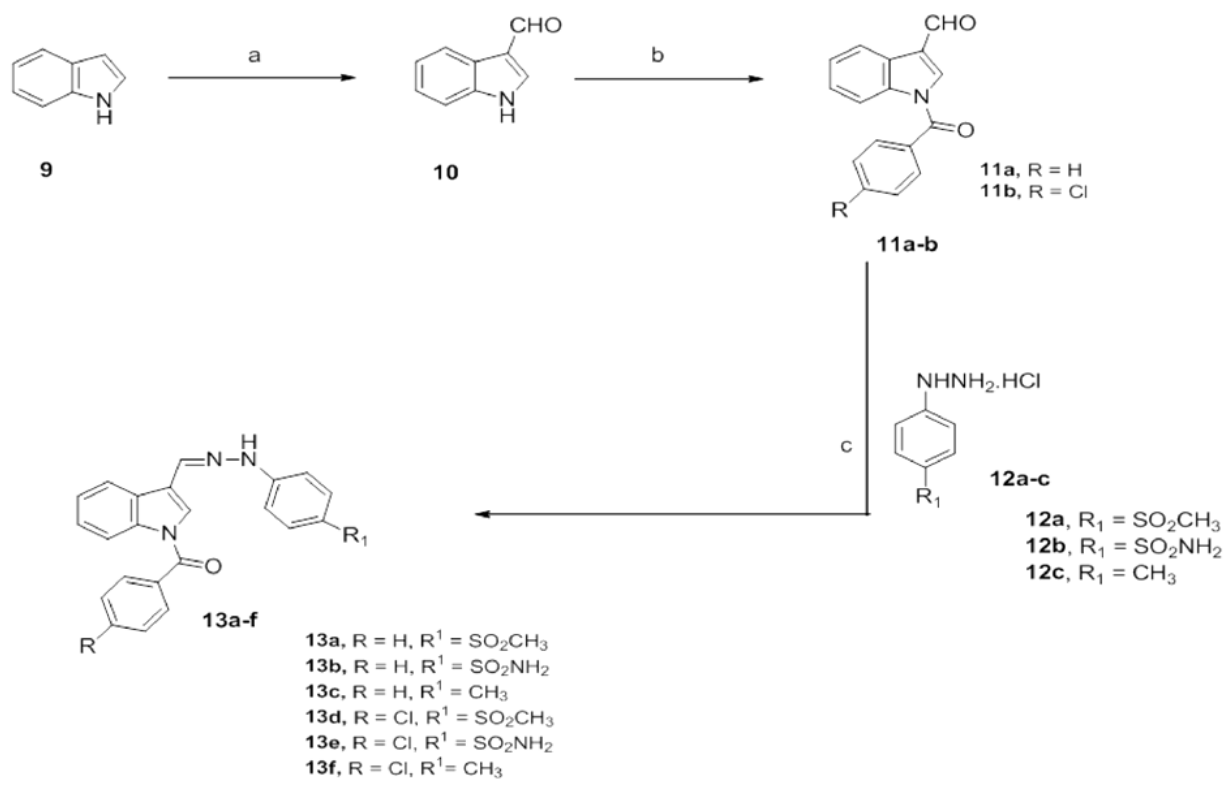

Reagents and reaction conditions: (a) $\mathrm{POCl}_{3}$, dry DMF, reflux, $8 \mathrm{~h}$; (b) appropriate acid chloride, NaH, DMF, RT, overnight; (c) abs. EtOH, gl.acetic acid, refux, 5-7 h. 


\section{Biological evaluation \\ In vitro cyclooxygenase (COX) inhibition assay}

The in vitro COX-1/COX-2 isozyme inhibition studies for the new indomethacin analogs 13a-f revealed a reversal of COX selectivity profile compared to indomethacin. The newly synthesized compounds showed relatively weak inhibition of COX-1 subtype with $\mathrm{IC}_{50}$ values $6.7-10.1 \mu \mathrm{M}$ while, they were highly potent inhibitors of COX-2 subtype with $\mathrm{IC}_{50}$ values 0.19 $0.53 \mu \mathrm{M}$ consequently compounds 13a-f were highly COX-2 selective with COX-2 selectivity indexes (S.I. $12.64-53.16$ ) in comparison with standard indomethacin $\left(\mathrm{COX}-1 \mathrm{IC}_{50}=0.039 \mu \mathrm{M}\right.$, COX-2 $\mathrm{IC}_{50}=0.49 \mu \mathrm{M}$ and COX-2 S.I. $\left.=0.079\right)($ Table 1$)$. Data from Table 1 revealed that i) all tested compounds 13a-f exhibited more potent inhibition for $\mathrm{COX}-2$ than $\mathrm{COX}-1$, ii) compounds having the $\mathrm{SO}_{2} \mathrm{Me}$ or $\mathrm{SO}_{2} \mathrm{NH}_{2}$ as COX-2 pharmacophore (13a,d with S.I. 37.83 and 51.11 respectively and 13b,e with S.I. 35.42 and 53.16 respectively) were more potent inhibitors of COX-2 than the corresponding analogs containing $\mathrm{CH}_{3}$ (13c-f with S.I. 12.64 and 14.79 respectively) and that confirms the importance of $\mathrm{SO}_{2} \mathrm{Me}$ for COX-2 selectivity, iii) compounds having chloro benzoyl moiety at indole N (13d,e,f with S.I. 51.11, 53.16, 14.79 respectively) exhibited higher potency for COX-2 than that having benzoyl one (13a,b,c with S.I. 37.83, 35.43, 12.64 respectively) and iv) within all compounds 13a-f, compounds 13e was the most potent COX-2 inhibitors and the most COX-2 selective and it was about 650 folds more COX-2 selective than indomethacin (COX-2 $\mathrm{IC}_{50}=0.49 \mu \mathrm{M}$, S.I. $\left.=0.079\right)$.

Table 1: In vitro COX-1 and COX-2 inhibition for compounds 13a-f, and reference drug (Indomethacin).

\begin{tabular}{cccc}
\hline \multirow{2}{*}{ Compounds } & \multicolumn{2}{c}{ COX Inhibition $\left(\mathbf{I C}_{\mathbf{5 0}} \boldsymbol{\mu M}\right)^{\mathbf{a}}$} & \multirow{2}{*}{$\begin{array}{c}\text { Selectivity } \\
\text { Index }^{\mathbf{b}}\end{array}$} \\
\cline { 2 - 3 } & $\mathbf{C O X}-\mathbf{C O X}-2$ & 0.23 & 37.83 \\
13a & 8.7 & 0.24 & 35.42 \\
13b & 8.5 & 0.53 & 12.64 \\
13c & 6.7 & 0.18 & 51.11 \\
13d & 9.2 & 0.19 & 53.16 \\
13e & 10.1 & 0.48 & 14.79 \\
13f & 7.1 & 0.49 & 0.079 \\
\hline
\end{tabular}

${ }^{\mathrm{a}}$ The concentration of test compound produce $50 \%$ inhibition of COX-1, COX2 enzyme, the results are the mean of two value obtained by assay of enzyme kits obtained from (Cayman Chemicals Inc., AnnArbor, MI, USA) where the deviation from the mean is $<10 \%$ of the mean value.

${ }^{\mathrm{b}}$ Selectivity index (COX-1 $\left.\mathrm{IC}_{50} / \mathrm{COX}-2 \mathrm{IC}_{50}\right)$.

\section{In vivo anti-inflammatory activity}

The anti-inflammatory activity of the prepared indomethacin derivatives 13a-f was evaluated using carrageeninduced rat paw edema test in comparison to indomethacin as a reference drug. Each compound was administered orally (10 $\mathrm{mg} / \mathrm{kg}$ ) immediately prior to induction of inflammation by carrageenan subcutaneous injection. The anti-inflammatory activity was then calculated based on paw-thickness changes at 1 , 3 and 6 hours after carrageenan injection as presented in Table 2.

A comparable study of the anti-inflammatory activity of the test compounds relative to indomethacin as a reference drug at different time intervals indicated that; after $1 \mathrm{~h}$, the indomethacin derivatives (13a-f) showed an intermediate edema inhibition activity between $41.6-58.7 \%$ and compounds $\mathbf{1 3 d}$,e were the most potent derivatives $(56.7,58.7 \%$ edema inhibition for $\mathbf{1 3 d}$ and 13e) in comparison with indomethacin (56\% edema inhibition). After 3 h, 13a-f showed a remarkable increase in edema inhibition percentage activities $60.6-87.2 \%$ and compound 13e was also the most potent derivatives $(87.2 \%$ edema) in comparison with indomethacin (86.7\% edema inhibition). After $6 \mathrm{~h}$, all compounds showed a little increase in edema inhibition percentage activities $65.8-91.5 \%$, while indomethacin showed a much increase in edema inhibition percentage activity $95.1 \%$.

The results, seen in (Table 2), were consistent with the in vitro results and in a similar manner to in vitro data, the in vivo data indicated the same conclusions; i) the presence $\mathrm{SO}_{2} \mathrm{Me}$ or $\mathrm{SO}_{2} \mathrm{NH}_{2}$ moiety (13a,d and 13b,e) increases the anti-inflammatory activity for this class of compounds, ii) 4-chlorobenzoyl is favorable over unsubstituted benzoyl for substitution at indole $\mathrm{N}$, iii) also, within all compounds 13a-f, the most potent COX-2 inhibitor and the most COX-2 selective (13e) was the most potent anti-inflammatory derivative after $3 \mathrm{~h}$ of carrageenan injection (91.5\% edema inhibition) in comparison with indomethacin (86.7\% edema inhibition).

Moreover, $\mathrm{ED}_{50}$ values for the most four potent derivatives (13a, 13b, 13d and 13e) were calculated after three hours from drug administration in comparison with reference drug indomethacin. The four derivatives (13a, 13b, 13d and 13e) showed good anti-inflammatory activities $\left(\mathrm{ED}_{50}=0.6,1.05,0.48\right.$ and $0.22 \mathrm{mg} / \mathrm{kg}$ respectively) in comparison with indomethacin $\left(\mathrm{ED}_{50}=0.4 \mathrm{mg} / \mathrm{kg}\right)$. The most COX-2 selective derivative (13e, about 650 folds more COX-2 selective than indomethacin) was the most potent anti-inflammatory derivative $\left(\mathrm{ED}_{50}=0.22 \mathrm{mg} / \mathrm{kg}=\right.$ approximately $1.8 \mathrm{x}$ potency of indomethacin).

Table 2: Percentage Inhibition of tested compounds (13a-f) at 1, 3, and $6 \mathrm{~h}$ after carrageenan injection in comparison with indomethacin.

\begin{tabular}{|c|c|c|c|c|}
\hline \multirow[b]{2}{*}{ Comp } & \multicolumn{3}{|c|}{$\begin{array}{c}\text { Oedema thickness }(\mathrm{mm}) \pm \text { SEM } \\
(\text { oedma inhibition } \%)^{\mathrm{a}}\end{array}$} & \multirow{2}{*}{ 產 } \\
\hline & $\underset{\text { (\% inhibition) }}{1 \mathrm{~h}}$ & $\begin{array}{c}3 \mathrm{~h} \\
\text { (\% inhibition) }\end{array}$ & $\begin{array}{c}\mathbf{6 ~ h} \\
\text { (\% inhibition) }\end{array}$ & \\
\hline Control & $2.118 \pm 0.025$ & $2.215 \pm 0.028$ & $1.878 \pm 0.029$ & $\ldots \ldots \ldots$ \\
\hline$\underset{n}{\text { Indomethaci }}$ & $\begin{array}{c}0.933 \pm 0.027 \\
(55.96 \%)\end{array}$ & $\begin{array}{c}0.295 \pm 0.033 \\
(86.68 \%)\end{array}$ & $\begin{array}{c}0.050 \pm 0.015 \\
(95.07 \%)\end{array}$ & 0.40 \\
\hline $13 \mathbf{a}$ & $\begin{array}{c}0.960 \pm 0.014 \\
(54.67 \%)\end{array}$ & $\begin{array}{c}0.408 \pm 0.023 \\
(81.58 \%)\end{array}$ & $\begin{array}{c}0.260 \pm 0.027 \\
(86.16 \%)\end{array}$ & 0.60 \\
\hline $13 b$ & $\begin{array}{l}1.013 \pm 0.025 \\
(52.17 \%) \\
\end{array}$ & $\begin{array}{l}0.400 \pm 0.021 \\
(81.94 \%) \\
\end{array}$ & $\begin{array}{l}0.215 \pm 0.028 \\
(88.55 \%) \\
\end{array}$ & 1.05 \\
\hline $13 c$ & $\begin{array}{c}1.238 \pm 0.024 \\
(41.55 \%) \\
\end{array}$ & $\begin{array}{l}0.878 \pm 0.026 \\
(60.63 \%) \\
\end{array}$ & $\begin{array}{c}0.643 \pm 0.026 \\
(65.76 \%) \\
\end{array}$ & NDc \\
\hline 13d & $\begin{array}{l}0.918 \pm 0.017 \\
\quad(56.66 \%)\end{array}$ & $\begin{array}{l}0.300 \pm 0.012 \\
\quad(86.46 \%)\end{array}$ & $\begin{array}{l}0.160 \pm 0.014 \\
\quad(91.48 \%)\end{array}$ & 0.48 \\
\hline $13 e$ & $\begin{array}{l}0.875 \pm 0.012 \\
\quad(58.69 \%)\end{array}$ & $\begin{array}{c}0.280 \pm 0.019 \\
(87.24 \%)\end{array}$ & $\begin{array}{l}0.176 \pm 0.010 \\
\quad(90.63 \%)\end{array}$ & 0.22 \\
\hline $13 f$ & $\begin{array}{l}1.200 \pm 0.017 \\
(43.34 \%)\end{array}$ & $\begin{array}{l}0.818 \pm 0.021 \\
\quad(63.07 \%)\end{array}$ & $\begin{array}{l}0.573 \pm 0.034 \\
(69.49 \%)\end{array}$ & $\mathrm{ND}^{\mathrm{c}}$ \\
\hline
\end{tabular}

${ }^{a}$ Data analyzed by one way ANOVA, $(\mathrm{n}=4), \mathrm{P}<0.05$, all were significant from control. ${ }^{\mathrm{b}} \mathrm{ED} 50$ values are determined at $3 \mathrm{~h}$ after oral administration of compounds and expressed in $\mathrm{mg} / \mathrm{Kg}$. ${ }^{\mathrm{c}} \mathrm{ND}=$ Not Determined. 


\section{Ulcerogenic liability test}

The most potent anti-inflammatory compounds (13a, 13b, 13d and 13e) were tested for their ulcerogenic liability in comparison with indomethacin (Table 3 ). The results revealed that, all tested compounds exhibited lower ulcerogenic liability (ulcer index $=8.87,6.40,6.97$ and 3.9 respectively) in comparison with indomethacin (Ulcer Index = 20.2). 13e (the most COX-2 selective derivative with about 650 folds more COX-2 selective than indomethacin and the most potent derivative has approximately $1.8 \mathrm{x}$ potency of indomethacin) was also the least ulcerogenic derivative (Ulcer Index = 3.9) which approximately one fifth ulcerogenic liability of indomethacin). The tested compounds (13a, 13b, 13d and 13e) were characterized by the presence of a $\mathrm{SO}_{2} \mathrm{Me}$ or $\mathrm{SO}_{2} \mathrm{NH}_{2}$ moiety (COX-2 pharmacophore) and absence of an acidic center, in contrast to indomethacin which having an acidic center and devoid of a COX-2 pharmcophore moiety. Consequently, these compounds possess more selectivity to COX2 isozyme and exhibited an excellent gastric safety profile compared to indomethacin which caused a great damage on gastric membrane that could be attributed to the high affinity to COX-1 over COX-2.

Table 3: Ulcer index of tested compounds $(\mathbf{1 3 a}, \mathbf{b}, \mathbf{d}, \mathbf{e})$ in comparison with indomethacin as a reference drug.

\begin{tabular}{ccccc}
\hline $\begin{array}{c}\text { Compound } \\
\text { No }\end{array}$ & $\begin{array}{c}\% \\
\text { Incidence }\end{array}$ & $\begin{array}{c}\text { Average no } \\
\text { of ulcer }\end{array}$ & $\begin{array}{c}\text { Average } \\
\text { severity }\end{array}$ & $\begin{array}{c}\text { ulcer } \\
\text { index }\end{array}$ \\
\hline $13 \mathrm{a}$ & 6 & 1.2 & 1.67 & $8.87^{\mathbf{a}}$ \\
$13 \mathrm{~b}$ & 4 & 1.0 & 1.4 & $6.4^{\mathbf{a}}$ \\
$13 \mathrm{~d}$ & 4 & 1.4 & 1.57 & $6.97^{\mathbf{a}}$ \\
$13 \mathrm{e}$ & 2 & 0.6 & 1.30 & $3.9^{\mathbf{a}}$ \\
Indomethacin & 8 & 9.2 & 3 & 20.2 \\
\hline
\end{tabular}

\section{Molecular Docking}

With the aim to understand the protein-inhibitor interaction of the synthesized compounds 13d,e within the COX-2 isozyme, molecular docking experiments were performed using X-ray crystal structure data for COX-2 obtained from the protein data bank (Kurumbail et al., 1996, Di Fiore et al., 2006). Valdecoxib (6) was used as a ligand for COX-2 isoform. The interaction of valdecoxib with COX-2 isozyme afforded three hydrogen bonding interactions and one hydrophobic interaction ; i) $\mathrm{NH}_{2}$ with His96 $\left(3.31 \mathrm{~A}^{\circ}\right)$, ii) $\mathrm{NH}_{2}$ with Thr199 (2.94 $\left.\mathrm{A}^{\circ}\right)$, iii) $\mathrm{SO}_{2}$ with Thr199 (2.92 $\left.\mathrm{A}^{\mathrm{o}}\right)$ and iv) phenyl ring with Asn67 $\left(4.73 \mathrm{~A}^{\mathrm{o}}\right)$.

In this work the docking results including the energy associated with intermolecular interactions (affinity in $\mathrm{Kcal} / \mathrm{mol}$ ) obtained upon computational docking for all compounds (13d,e and valdecoxib) within COX-2 active site and the hydrogen bonding interactions between the amino acid residues and functional groups of the compounds are listed in Table 4. With COX-2, compounds 13d,e showed excellent binding interactions (affinity in $\mathrm{Kcal} / \mathrm{mol}$ ranges from -6.7235 to -7.0539 with three or four hydrogen bonding interactions) in comparison with valdecoxib (-6.7084 with 3 hydrogen bonding interactions). The docking results were consistent with the in vitro inhibitory activity and suggested that compounds (13d) and (13e) good selectivity against COX-2 isozyme similar to valdecoxib (6) which both of them contain pharmacophore of COX-2 $\left(\mathrm{SO}_{2} \mathrm{Me}\right.$ or $\left.\mathrm{SO}_{2} \mathrm{NH}_{2}\right)$ (Fig. 3-5).

Table 4: Molecular modeling data for compounds 13d,e and valdecoxib during docking in COX-2 (PDB:ID 2AW1) active site.

\begin{tabular}{|c|c|c|c|c|c|c|}
\hline \multirow[b]{2}{*}{ Compound } & \multicolumn{6}{|l|}{$\mathrm{COX}-2$} \\
\hline & $\begin{array}{l}\text { Affinity } \\
\text { Kcal/mol }\end{array}$ & $\begin{array}{l}\text { Affinity } \\
\text { Kcal/mol }\end{array}$ & $\begin{array}{l}\text { Dista } \\
\text { from } \\
\text { main }\end{array}$ & $\begin{array}{l}\text { ce (in } \mathrm{A}^{\mathrm{o}} \text { ) } \\
\text { esidue }\end{array}$ & $\begin{array}{l}\text { Functional } \\
\text { group }\end{array}$ & Interaction \\
\hline \multirow[t]{4}{*}{ 13d } & -7.0539 & -2.8 & 2.82 & Thr199 & $-\mathrm{SO}_{2}$ & H-acceptor \\
\hline & & -0.7 & 3.28 & His119 & $-\mathrm{SO}_{2}$ & $\mathrm{H}$-acceptor \\
\hline & & -2.0 & 3.32 & His96 & $-\mathrm{SO}_{2}$ & $\mathrm{H}$-acceptor \\
\hline & & -3.6 & 2.99 & Asn67 & $=\mathrm{N}-$ & $\mathrm{H}$-acceptor \\
\hline \multirow[t]{3}{*}{$\overline{13 e}$} & -6.7235 & -3.9 & 2.94 & Thr199 & $-\mathrm{SO}_{2}$ & H-acceptor \\
\hline & & -1.6 & 3.11 & Thr199 & $-\mathrm{NH}_{2}$ & H-donor \\
\hline & & -0.7 & 3.29 & His96 & $-\mathrm{NH}_{2}$ & $\mathrm{H}$-acceptor \\
\hline \multirow[t]{4}{*}{ Valdecoxib } & -6.7084 & -3.7 & 2.92 & Thr199 & $-\mathrm{SO}_{2}$ & H-acceptor \\
\hline & & -3.5 & 2.94 & Thr199 & $-\mathrm{NH}_{2}$ & H-donor \\
\hline & & -0.7 & 3.31 & His96 & $-\mathrm{NH}_{2}$ & $\mathrm{H}$-acceptor \\
\hline & & -0.8 & 4.73 & Asn67 & -Ph-ring & pi-H \\
\hline
\end{tabular}

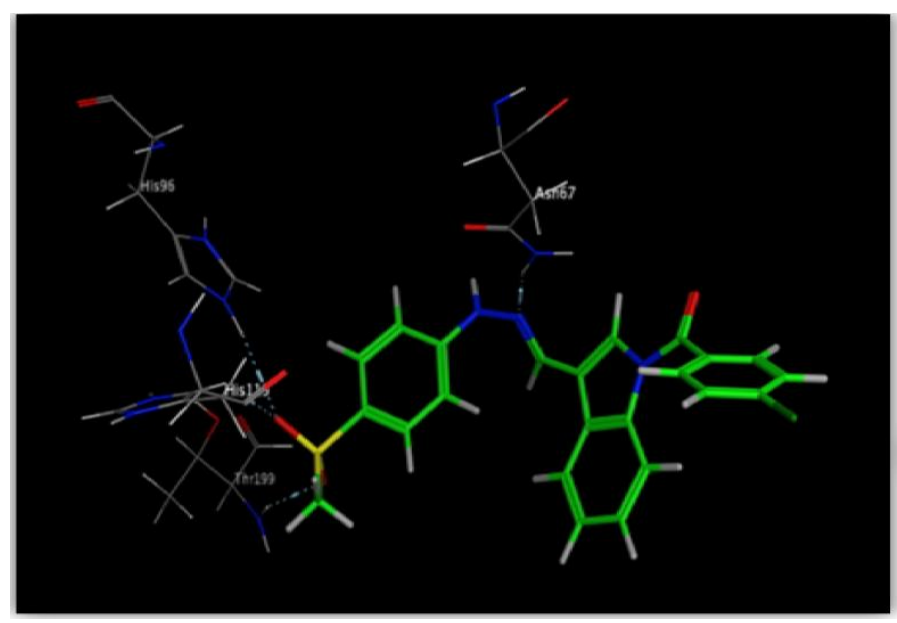

(a)

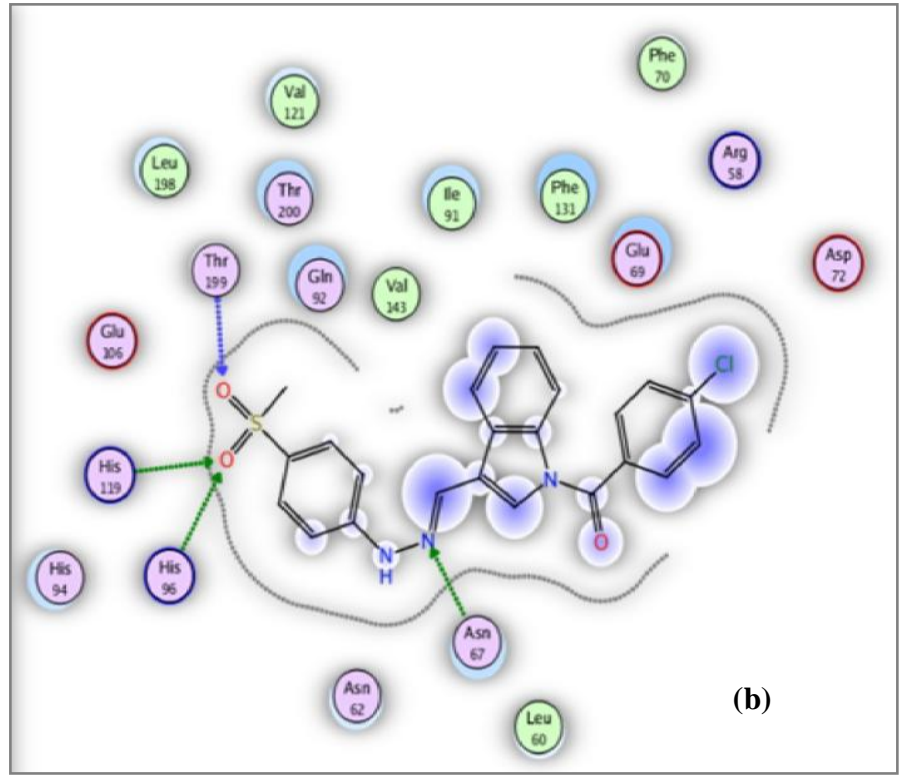

Fig. 3: Binding of the compound $\mathbf{1 3 d}$ inside COX-2 active site. a) The $3 \mathrm{D}$ proposed binding mode inside the active site of COX-2 resulting from docking, the most important amino acids are shown together with their respective numbers. b) $2 \mathrm{D}$ interaction. 


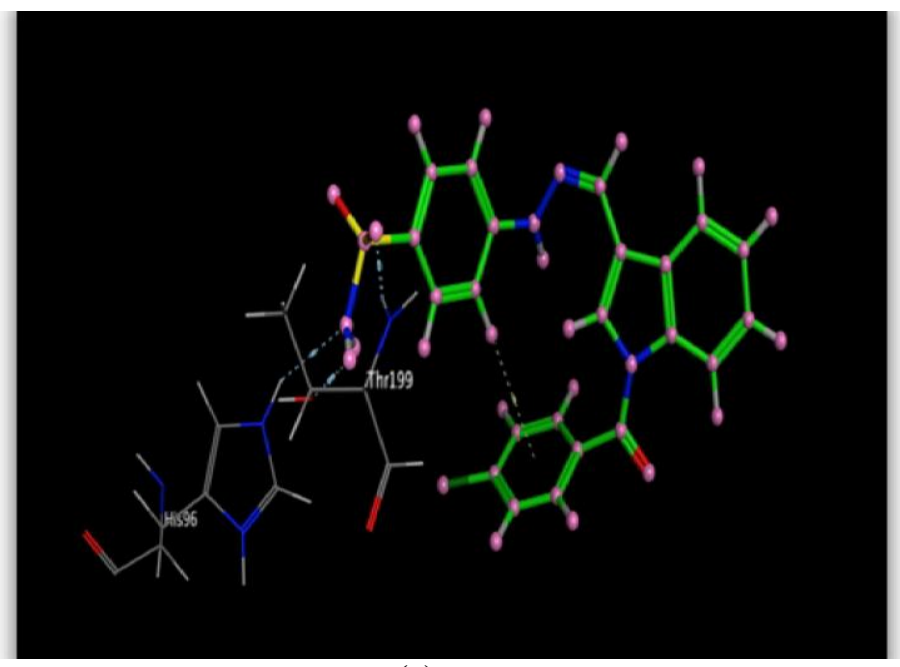

(a)

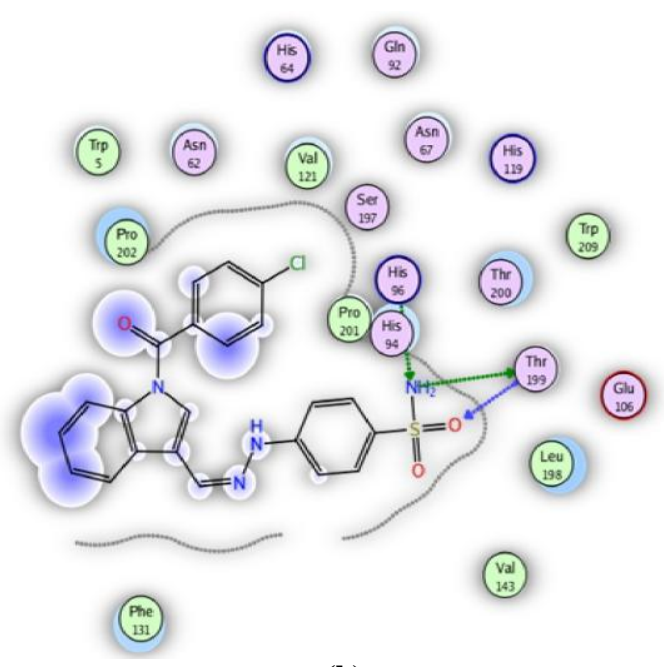

(b)

Fig. 4: Binding of the compound 13e inside COX-2 active site. a) The 3D proposed binding mode inside the active site of COX-2 resulting from docking, the most important amino acids are shown together with their respective numbers. b) $2 \mathrm{D}$ interaction.

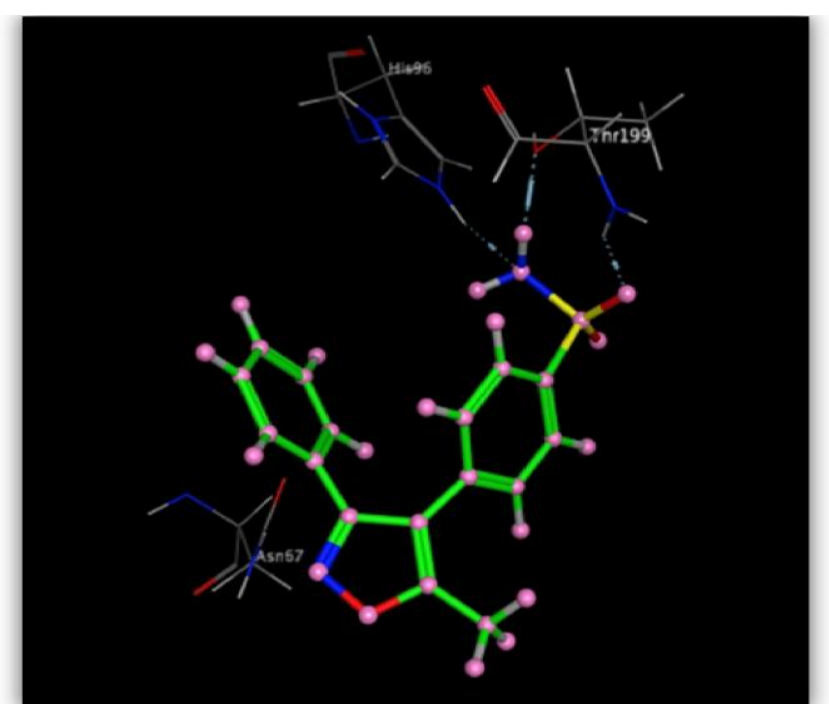

(a)

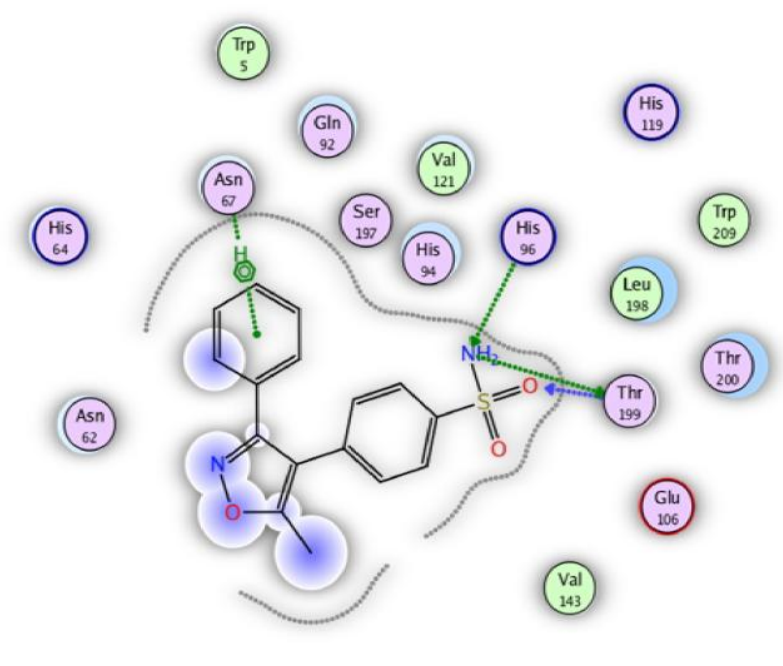

(b)

Fig. 5: Binding of the valdecoxib inside $\mathrm{COX}-2$ active site. a) The $3 \mathrm{D}$ proposed binding mode inside the active site of $\mathrm{COX}-2$ resulting from docking, the most important amino acids are shown together with their respective numbers. b) $2 \mathrm{D}$ interaction.

\section{Financial support and sponsorship: Nil.}

Conflict of Interests: There are no conflicts of interest.

\section{REFERENCES}

Abdelazeem AH, Abdelatef SA, El-Saadi MT, Omar HA, Khan SI, McCurdy CR, El-Moghazy SM. Novel pyrazolopyrimidine derivatives targeting COXs and iNOS enzymes; design, synthesis and biological evaluation as potential anti-inflammatory agents. Eur. J. Pharm .Sci., $2014 ; 62: 197-211$.

Abdelazeem AH, Khan SI, White SW, Sufka KJ, McCurdy CR. Design, synthesis and biological evaluation of bivalent benzoxazolone and benzothiazolone ligands as potential anti-inflammatory/analgesic agents. Bioorg. Med. Chem., 2015; 23.3259-3248:

Abdellatif KR, Abdelall EK, Fadaly WA, Kamel GM. Synthesis, cyclooxygenase inhibition, and anti-inflammatory evaluation of novel diarylheterocycles with a central pyrazole, pyrazoline, or pyridine ring. Med. Chem. Res., 2015; 24:2632-2644.
Abdellatif KR, Abdelgawad MA, Labib MB, Zidan TH. Synthesis, cyclooxygenase inhibition, anti-inflammatory evaluation and ulcerogenic liability of novel triarylpyrazoline derivatives as selective COX-2 inhibitors. Bioorg. Med. Chem. Lett., 2015; 25: 5787-91.

Abdellatif KR, Chowdhury MA, Dong Y, Das D, Yu G, Velázquez C, Suresh MR, Knaus EE. Diazen-1-ium-1, 2-diolated nitric oxide donor ester prodrugs of 5-(4-carboxymethylphenyl)-1-(4methanesulfonylphenyl)-3-trifluoromethyl-1H-pyrazole and its aminosulfonyl analog: synthesis, biological evaluation and nitric oxide release studies. Bioorg. Med. Chem., 2009; 17:5182-5188.

Abdellatif KR, Chowdhury MA, Dong Y, Velázquez C, Das D, Suresh MR, Knaus EE. Diazen-1-ium-1, 2-diolated nitric oxide donor ester prodrugs of 5-(4-hydroxymethylphenyl)-1-(4-aminosulfonylphenyl)-3trifluoromethyl-1H-pyrazole and its methanesulfonyl analog: synthesis, biological evaluation and nitric oxide release studies. Bioorg. Med. Chem., 2008; 16:9694-9698.

Abdellatif KR, Chowdhury MA, Knaus EE. Synthesis of new 1-[4-methane(amino)sulfonylphenyl)]-5-[4-(aminophenyl)]-3- 
trifluoromethyl-1H-pyrazoles. J. Heterocyclic Chem., 2008; 45:17071710 .

Abdellatif KR, Lamie PF, Omar HA. 3-Methyl-2-phenyl-1substituted-indole derivatives as indomethacin analogs: design, synthesis and biological evaluation as potential anti-inflammatory and analgesic agents. J. Enzyme Inhib. Med. Chem., 2016; 31:318-324.

Abuo-Rahma GE-DA, Abdel-Aziz M, Farag NA, Kaoud TS. Novel 1-[4-(Aminosulfonyl) phenyl]-1H-1, 2, 4-triazole derivatives with remarkable selective COX-2 inhibition: Design, synthesis, molecular docking, anti-inflammatory and ulcerogenicity studies. Eur. J. Med. Chem., 2014; 83:398-408.

Al-Hourani BJ, Sharma SK, Mane JY, Tuszynski J, Baracos V, Kniess T ,Suresh M, Pietzsch J, Wuest F. Synthesis and evaluation of 1, 5diaryl-substituted tetrazoles as novel selective cyclooxygenase-2 (COX-2) inhibitors. Bioorg. Med. Chem. Lett., 2011; 21:1823-1826.

Chowdhury MA, Abdellatif KR, Dong Y, Yu G, Huang Z, Rahman M, Das D, Velázquez CA, Suresh MR, Knaus EE. Celecoxib analogs possessing a $\mathrm{N}$-(4-nitrooxybutyl) piperidin-4-yl or $\mathrm{N}$-(4nitrooxybutyl)-1, 2, 3, 6-tetrahydropyridin-4-yl nitric oxide donor moiety: synthesis, biological evaluation and nitric oxide release studies. Bioorg. Med. Chem. Lett., 2010; 20:1324-1329.

Di Fiore A, Pedone C, D'Ambrosio K, Scozzafava A, De Simone G, Supuran CT. Carbonic anhydrase inhibitors: valdecoxib binds to a different active site region of the human isoform II as compared to the structurally related cyclooxygenase II 'selective'inhibitor celecoxib. Bioorg. Med. Chem. Lett., 2006; 16:437-442.

Dogné J-M, Supuran CT, Pratico D. Adverse cardiovascular effects of the coxibs. J. Med. Chem., 2005; 48:2251-2257.

El-Nezhawy AO, Biuomy AR, Hassan FS, Ismaiel AK, Omar HA. Design, synthesis and pharmacological evaluation of omeprazole-like agents with anti-inflammatory activity. Bioorg. Med. Chem., 2013; $21: 1661-1670$

Guillon R, Logé C, Pagniez F, Ferchaud-Roucher V, Duflos M, Picot C, Pape PL .Synthesis and in vitro antifungal evaluation of 2-(2, 4difluorophenyl)-1-[(1 H-indol-3-ylmethyl) methylamino]-3-(1 H-1, 2, 4triazol-1-yl) propan-2-ols. J. Enzyme Inhib. Med. Chem., 2011; 26:261269.

Hassan GS, Abou-Seri SM, Kamel G, Ali MM. Celecoxib analogs bearing benzofuran moiety as cyclooxygenase-2 inhibitors: design, synthesis and evaluation as potential anti-inflammatory agents. Eur. J. Med. Chem., 2014; 76:482-493.

Hu W, Guo Z, Chu F, Bai A, Yi X, Cheng G, Li J. Synthesis and biological evaluation of substituted 2-sulfonyl-phenyl-3-phenylindoles: a new series of selective COX-2 inhibitors. Bioorg. Med. Chem., 2003; 11:1153-1160.

Huang Z, Velázquez C, Abdellatif K, Chowdhury M, Jain S, Reisz J, DuMond J, King SB, Knaus E. Acyclic triaryl olefins possessing a sulfohydroxamic acid pharmacophore: synthesis, nitric oxide/nitroxyl release, cyclooxygenase inhibition, and anti-inflammatory studies. Org. Biomol. Chem., 2010; 8:4124-4130.

Kalgutkar AS, Crews BC, Saleh S, Prudhomme D, Marnett LJ. Indolyl esters and amides related to indomethacin are selective COX-2 inhibitors. Bioorg. Med. Chem., 2005; 13:6810-6822.
Khanna S, Madan M, Vangoori A, Banerjee R, Thaimattam R, Basha SJS, Ramesh M, Casturi SR, Pal M. Evaluation of glycolamide esters of indomethacin as potential cyclooxygenase-2 (COX-2) inhibitors. Bioorg. Med. Chem., 2006; 14:4820-4833.

Kumar AS, Rao PA, Nagarajan R. Synthesis of pyrido [2, 3-b] indoles and pyrimidoindoles via Pd-catalyzed amidation and cyclization. Org. Biomol. Chem., 2012; 10: 5084-5093..

Kurumbail RG, Stevens AM, Gierse JK, McDonald JJ. Structural basis for selective inhibition of cyclooxygenase-2 by antiinflammatory agents. Nature, 1996; 384:644.

Lamie PF, Ali WA, Bazgier V, Rárová L. Novel N-substituted indole Schiff bases as dual inhibitors of cyclooxygenase-2 and 5lipoxygenase enzymes: Synthesis, biological activities in vitro and docking study. Eur. J. Med. Chem., 2016; 123:803-813.

Rathish I, Javed K, Ahmad S, Bano S, Alam M, Pillai K, Singh $\mathrm{S}$, Bagchi V. Synthesis and antiinflammatory activity of some new 1, 3, 5trisubstituted pyrazolines bearing benzene sulfonamide. Bioorg. Med. Chem. Lett., 2009; 19:255-258.

Roschek Jr B, Fink RC, Li D, McMichael M, Tower CM, Smith RD, Alberte RS. Pro-inflammatory enzymes, cyclooxygenase 1, cyclooxygenase 2 , and 5-lipooxygenase, inhibited by stabilized rice bran extracts. J. Med. Food, 2009; 12:615-623.

Singh P, Kaur M, Holzer W. Synthesis and evaluation of indole, pyrazole, chromone and pyrimidine based conjugates for tumor growth inhibitory activities-Development of highly efficacious cytotoxic agents. Eur. J. Med. Chem., 2010; 45:4968-4982.

Wang J, Sun G, Li Z, Mai W, Xie J. Synthesis and biological evaluation of curcumin analogues having a piperidone core as potential antioxidant agents. J. Chem. Res., 2012; 36:63-65.

Zebardast T, Zarghi A, Daraie B, Hedayati M, Dadrass OG. Design and synthesis of 3-alkyl-2-aryl-1, 3-thiazinan-4-one derivatives as selective cyclooxygenase (COX-2) inhibitors. Bioorg. Med. Chem. Lett., 2009; 19:3162-3165.

\section{How to cite this article:}

Abdellatif KRA, Elsaady MT, Amin NH, Hefny AA. Synthesis, cyclooxygenase inhibition, anti-inflammatory evaluation and gastric liability of some novel indole derivatives as a selective COX-2 inhibitors. J App Pharm Sci, 2017; 7 (08): 069-077. 